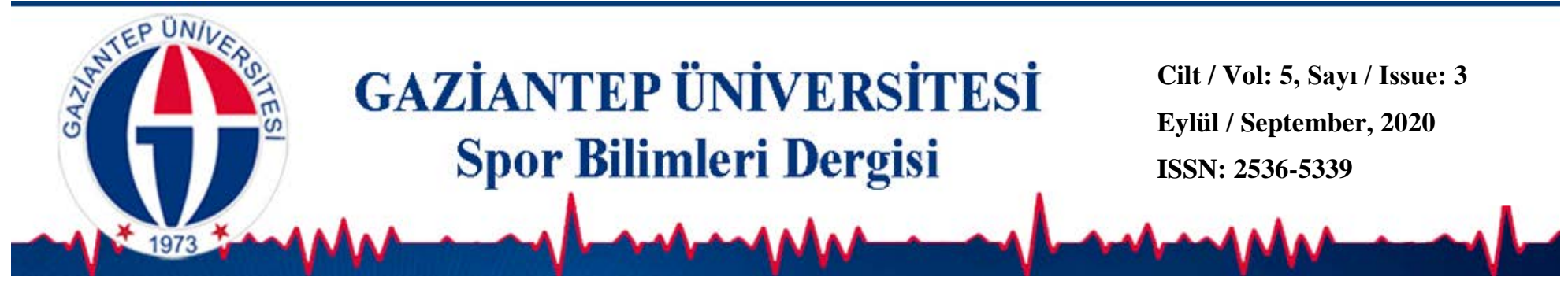

\title{
Belediyelerin Sunduğu Spor Hizmetlerine Yönelik Halkın Algı ve Beklentileri - Adapazarı İlçesi Örneği
}

\author{
Gökhan ÇAKMAK ${ }^{*}$ (D) $\quad$ Faik Orhun TAPŞIN ${ }^{2}$ (D) \\ ${ }^{1}$ Kocaeli Üniversitesi, Spor Bilimleri Fakültesi, KOCAELI \\ ${ }^{2}$ Gazi Üniversitesi Să̆lık Bilimleri Enstitüsü, ANKARA
}

\section{DOI: 10.31680/gaunjss.688748}

Orijinal Makale / Original Article

Geliș Tarihi / Received: 13.02.2020
Kabul Tarihi / Accepted: 07.09.2020

Yayın Tarihi / Published: 14.09.2020

\section{Öz}

Belediyeler, belirli bir coğrafyada yaşayan halkın ortak ihtiyaçlarını gidermek üzere karar organları halkça seçilen, yasalarca belirlenmiş görev ve yetkileri olan, kendine özel geliri, bütçesi ve personeli olan kamu tüzel kişileri şeklinde tanımlanabilir. Belediyelerin en önemli görevlerinden biri de sorumlu olduğu alan içerisinde yaşayan halka spor hizmetleri sunmaktadır. Bu çalışmanın amacı halkın belediyelerin verdiği spor hizmetlerine yönelik algı ve beklentilerinin araştırımasıdır. Bu çalışmada karma yöntem kullanılmıştır. Anket formu, Çoban (2002) tarafından spor hizmetleri konusunda halkın belediyelerden beklentilerini araştırmak amacıyla hazırlanmış ve Avcılar (2016) tarafından düzenlenmiş olup araştırmacılar tarafından güncellenmiştir. Çalışmaya Sakarya ili merkez ilçesi olan Adapazarı'nda ikamet eden ve kolayda örneklem yoluyla seçilen 288 kişi katılmıştır. Verilerin analizinde SPSS 25.0 programı kullanılmıştır. Yüzde frekans analizinin yanı sıra veriler normal dağılmadığı için parametrik olmayan testlerden Mann Whitney-U ve Kruskal Wallis testleri kullanıımıştır. Katılımcılara spor hizmetleri ile ilgili beklentilerine yönelik açık uçlu bir soru sorulmuş ve bu sorunun deşifre ve analizi ise araştırmacılar tarafından yapılmıştır. Çalışmanın sonucunda belediyelerin spor hizmetlerini halkın beklentilerini göz önünde bulundurarak sunması gerektiği, belediyelerin spor hizmeti sunmasının halkla olan iletişimini kuvvetlendirdiği, oyun ve spor alanları yapmanın belediyelerin sorumluluğunda olduğu; katıımcıların verdikleri yanıtların yaş, eğitim durumu ve spor hizmetlerini yeterli bulup bulmama değişkenlerine göre farklılık gösterdiği; ilçede bulunan tesis sayısının halk tarafından yeterli bulunmadığı, daha nitelikli ve ücretsiz spor salonlarının yapılması gerektiği, sunulan spor hizmetlerinin çeşitlendirilerek reklam ve tanıtım faaliyetlerinin arttırılması gerektiği sonuçlarına ulaşılmıştır.

Anahtar Kelimeler: Spor hizmetleri, belediye, halk algısı

\section{Public Perceptions and Expectations for Sports Services Offered by Municipalities - Example of Adapazarı District}

\begin{abstract}
Municipalities are defined as public legal entities whose decision-making bodies are chosen by the public to fulfill the common needs of the people living in a specific geographical area, have duties and authorities determined by law, and have special income, budget and personnel. One of the most important duties of the municipalities is to provide sports services to the people living in the area in which it is responsible. The aim of this study is to investigate the perceptions and expectations of the public towards the sports services provided by the municipalities. The mixed method was used in this study. The questionnaire form was prepared by Çoban (2002) in order to investigate the expectations of the people from the municipalities regarding sports services, and was prepared by Avcılar (2016) and updated by the researchers. The study was conducted with 288 people, who were selected by sampling easily and living in Adapazarı, a central district of Sakarya. SPSS 25.0 program was used for data analysis. In addition to percentage frequency analysis, Mann Whitney-U and Kruskal Wallis tests were used as nonparametric tests since the data were not normally distributed. An open-ended question was asked to the participants about their expectations about sports services, and this question was deciphered and analyzed by the researchers. As a result of the study, it is stated that municipalities should provide sports services by considering the expectations of the public, the provision of sports services by the municipalities strengthens the communication with the public, and it is the responsibility of the municipalities to make games and sports areas; participants' responses differed according to age, educational background, and whether they found sports services adequate; It was concluded that the number of facilities in the district is not sufficient by the public, more qualified and free sports halls should be built, the sports services offered should be diversified and advertising and promotion activities should be increased.
\end{abstract}

Keywords: Sports services, municipality, public perception

\footnotetext{
* Sorumlu Yazar: Gökhan ÇAKMAK
}

E-mail: cakmakgokhan23@gmail.com

Bu çalışma 17.Uluslararası Spor Bilimleri Kongresi'nde sözel bildiri olarak sunulmuştur. 
Çakmak, G. ve Tapşın, F.O. (2020). Belediyelerin Sunduğu Spor Hizmetlerine Yönelik Halkın Algı ve Beklentileri - Adapazarı İlçesi Örneği. Gaziantep Üniversitesi Spor Bilimleri Dergisi, 5(3), 263-275.

\section{Giriş}

Belediyeler, belirli bir coğrafyada yaşayan halkın ortak ihtiyaçlarını gidermek üzere karar organları halkça seçilen, yasalarca belirlenmiş görev ve yetkileri olan, kendine özel geliri, bütçesi ve personeli olan kamu tüzel kişileri şeklinde tanımlanabilir (Atalay, Yücel ve Korkmaz, 2016). İnsan istek ve ihtiyaçlarının karşılanması noktasında birincil derecede sorumlu kurumlar belediyelerdir ve sosyal devlet olgusunun yereldeki tezahürleri olarak algılanabilirler (Yücel, Atalay ve Korkmaz, 2016). Spor, bir bölgede yaşayan halk için belediyenin yapabileceği en önemli hizmet alanlarından biridir (Atalı, 2015). Spor, kişisel ve toplumsal sağlığı koruyucu ve geliştirici niteliklere sahip bir olgu olduğu için bir ihtiyaçtır ve belediyeler tarafından topluma sunulması gereken bir hizmettir. Özellikle boş zamanlarını değerlendirme arayışında olan insanlar için spor önemli bir konumdadır.

Sporun kitlelere yayılmasında belediyeler önemli bir konumda yer almaktadır. Sporun yayılması için belediyeler gelirlerinin bir kısmını projelere ve çalışmalara ayırmaktadır (Akşar, 2010). Halkın sporu bir yaşam biçimi olarak kabul etmesini ve düzenli olarak spor yapmasını sağlamak diğer kurumların yanı sıra belediyelerin en önemli amaçlarından biri olmalıdır (Zengin ve Öztaş, 2008). Spor faaliyetleri, çeşitli alt sektörler ve farklı kurumsal ortamlarda, halka yönelik birçok spor organizasyonuyla teşvik edilmektedir (Teixeira ve Riberio, 2016). Ülkemizde özellikle büyükşehir belediyeleri birçok branşta faaliyet spor kulübüne sahip olmasına rağmen çoğu belediye halen en ciddi yatırımlarını kentin futbol takımına yapmaktadır. Belediyelerin asli görevi performans sporunu değil herkes için sporu desteklemek olmalıdır.

Halka spor hizmeti sunmak belediyelere yasalarla da yüklenen görevlerden biri olarak karşımıza çıkmaktadır (Kurtipek ve Yenel, 2019). Anayasa'nın 59. maddesinde belirtilen devlet kavramı ile belediyelere anayasal bir sorumluluk yüklenmiş ve belediyeler devletin yereldeki temsilcileri olarak görülmüştür (Çoban ve Devecioğlu, 2006). 5216 sayılı Büyükşehir Belediyesi Kanunu (2004) ve 5393 sayılı Belediye Kanunu (2005) ile de belediyelere halka spor hizmeti sunma görevi verilmiştir.

Temelde kitle sporunun yaygınlaştırılması ve herkes için spor anlayışının tüm ülkeye yayılmasının belediyelerin asli görevleri arasında olduğu söylenebilir (Yücel, Atalay ve Korkmaz, 2016). Sporla ilgili olarak aktivite ve eğlence merkezleri vb. yerleri yapmak, yaptırmak, işletmek veya işlettirmek belediyelerin sorumluluğundadır (Üzüm ve diğerleri, 2016). Fonksiyonları gereği sürekli halkla iç içe olan belediyelerin önemli bir iletişim aracı olan spor hizmetlerini halka sunması sağlıklı bir toplum yapısı 
Çakmak, G. ve Tapşın, F.O. (2020). Belediyelerin Sunduğu Spor Hizmetlerine Yönelik Halkın Algı ve Beklentileri - Adapazarı İlçesi Örneği. Gaziantep Üniversitesi Spor Bilimleri Dergisi, 5(3), 263-275.

oluşmasında önemli bir adım olacaktır (Çoban, 2002). Ayrıca, belediyeler tarafından spor hizmeti sunulması halk ile belediyeler arasındaki ilişkinin kuvvetlenmesi açısından da önemlidir.

Belediyeler, halkın spora ilişkin beklenti, istek ve ihtiyaçlarının karşıllanmasında yerel ölçekte sorumlu idari birimlerdir ve dolayısıyla anayasal haklardan biri olan spordan en yüksek faydanın sağlanması ve beklentilerin karşılanması noktasında sorumludurlar (Atalay, Yücel ve Korkmaz, 2016). Bu bilgiler ışığında belediyelerin spor hizmetlerinin halk tarafından nasıl karşılandığının tespitinin, belediyelerin yapacağı yatırımların ve sunacağı hizmet çeşitliliğinin belirlenmesinde oldukça önemli olduğu söylenebilir. Bu doğrultuda bu çalışmanın amacı, halkın belediyelerin verdiği spor hizmetlerine yönelik algı ve beklentilerinin araştırıımasıdır.

\section{Yöntem}

\section{Araştırmanın Modeli}

$\mathrm{Bu}$ araştırmada, halkın belediyelerin sunduğu spor hizmetlerine yönelik algılarını ve beklentilerini daha net bir şekilde tespit edebilmek amacıla karma yöntem kullanıımıştır. Karma yöntem, bir çalışmada nicel ve nitel yöntemin bir arada kullanılması şeklinde açıklanabilir (Baki ve Gökçek, 2012). Nicel ve nitel yöntemi bir arada kullanmak araştırma problemlerinin daha iyi anlaşılmasını sağladığı (Creswell, 2006) için bu araştırmada karma yöntem tercih edilmiştir.

\section{Evren ve Örneklem}

Çalışmanın evrenini güncel verilere göre Sakarya ili merkez ilçesi olan Adapazarı'nda ikamet eden 271.515 kişi oluşturmaktadır (tuik.gov.tr, Erişim Tarihi: 03.08.2019). Örneklem grubunu ise kolayda örneklem yoluyla seçilen toplam 288 katılımcı oluşturmuştur. Örneklem büyüklüğünün hesaplanmasında bazı araştırmacılar soru sayısının 10 katı örneklem grubu olması gerektiğini (Nunnally, 1978; Gürbüz ve Şahin, 2018), bazı araştırmacılar 4 katı olması gerektiğini (Tabachnick ve Fidel, 1996) bazı araştırmacılar ise soru sayısının 5 katı örneklem grubu olması gerektiğini belirtmişlerdir (Büyüköztürk ve diğerleri, 2008). Bu bilgiler doğrultusunda ulaşılan örneklem büyüklüğünün yeterli olduğu kabul edilmiştir. 
Çakmak, G. ve Tapşın, F.O. (2020). Belediyelerin Sunduğu Spor Hizmetlerine Yönelik Halkın Algı ve Beklentileri - Adapazarı İlçesi Örneği. Gaziantep Üniversitesi Spor Bilimleri Dergisi, 5(3), 263-275.

Tablo 1: Örneklem Grubunun Demografik Özellikleri

Demografik Değişkenler Alt Gruplar

Frekans (f) Yüzde (\%)

\begin{tabular}{|c|c|c|c|}
\hline \multirow{2}{*}{ Cinsiyet } & Erkek & 147 & 51,0 \\
\hline & Kadın & 141 & 49,0 \\
\hline \multirow{5}{*}{ Yaş } & $16-25$ & 36 & 12,5 \\
\hline & $26-35$ & 76 & 26,4 \\
\hline & $36-45$ & 140 & 48,6 \\
\hline & $46-55$ & 24 & 8,3 \\
\hline & 56 ve üzeri & 12 & 4,2 \\
\hline \multirow{5}{*}{ Meslek } & Kamu çalışanı & 69 & 24,0 \\
\hline & Özel sektör çalışanı & 121 & 42,0 \\
\hline & Öğrenci & 20 & 6,9 \\
\hline & Emekli & 12 & 4,2 \\
\hline & Ev hanımı & 66 & 22,9 \\
\hline \multirow{6}{*}{ Bu İlçede İkamet Ettiği Süre } & 1 yıldan az & 5 & 1,7 \\
\hline & $1-5$ yıl & 28 & 9,7 \\
\hline & 6-10 yıl & 39 & 13,5 \\
\hline & $11-15 \mathrm{yll}$ & 33 & 11,5 \\
\hline & $16-20 \mathrm{yll}$ & 33 & 11,5 \\
\hline & 21 yıl ve üzeri & 150 & 52,1 \\
\hline \multirow{4}{*}{ Aylık Gelir Düzeyi } & 2000 TL ve altı & 78 & 27,1 \\
\hline & 2001-4000 TL & 121 & 42,0 \\
\hline & 4001-6000 TL & 60 & 20,8 \\
\hline & 6001 ve üzeri & 29 & 10,1 \\
\hline \multirow{5}{*}{ Eğitim Durumu } & İlkokul & 24 & 8,3 \\
\hline & Ortaokul & 27 & 9,4 \\
\hline & Lise & 100 & 34,7 \\
\hline & Üniversite & 109 & 37,8 \\
\hline & Lisansüstü & 28 & 9,7 \\
\hline \multirow{2}{*}{$\begin{array}{l}\text { Düzenli Olarak Spor Yapma } \\
\text { Durumu }\end{array}$} & Evet & 67 & 23,3 \\
\hline & Hayır & 221 & 76,7 \\
\hline \multirow{2}{*}{$\begin{array}{l}\text { Spor Hizmetlerini Yeterli } \\
\text { Bulup Bulmama Durumu }\end{array}$} & Evet & 80 & 27,8 \\
\hline & Hayır & 208 & 72,2 \\
\hline
\end{tabular}

Tablo 1 incelendiğinde katıımcıların çoğunun erkek, 36-45 yaş grubunda, özel sektör çalışanı, 21 yıl ve daha üstü sürelerdir Adapazarı ilçesinde oturan, 2001-4000 TL arası gelir düzeyine sahip ve üniversite mezunu olduğu; çoğunun düzenli olarak spor yapmadığı ve sunulan spor hizmetlerini yeterli bulmadığı görülebilir.

\section{Verilerin Toplanması}

Verilerin toplanmasında kullanılan anket formu, Çoban (2002) tarafından spor hizmetleri konusunda halkın belediyelerden beklentilerini araştırmak amacıyla hazırlanmış ve Avcılar (2016) tarafından çeşitli çalışmalar derlenerek düzenlenmiş 
Çakmak, G. ve Tapşın, F.O. (2020). Belediyelerin Sunduğu Spor Hizmetlerine Yönelik Halkın Algı ve Beklentileri - Adapazarı İlçesi Örneği. Gaziantep Üniversitesi Spor Bilimleri Dergisi, 5(3), 263-275.

olan formun araştırmacılar tarafından güncellenmesiyle oluşturulmuştur. Araştırmada kullanılan anket formunda katılımcıların demografik bilgilerini belirlemeye yönelik 7 soru, araştırma yapılan ilçede sunulan spor hizmetlerini yeterli bulup bulmadıklarını belirlemeye yönelik iki seçenekli (evet/hayır) 1 soru, spor hizmetleri ve spor tesisleriyle alakalı düşüncelerini öğrenmeye yönelik olarak 5'li likert şeklinde hazırlanmış 18 soru ve spor hizmetlerini yeterli bulmayanların beklentilerini belirlemek için hazırlanmış 1 adet açık uçlu soru yer almaktadır. Hazırlanan anket formu araştırmacılar tarafından katılımcılara bizzat dağıtılmış ve doldurulması sağlanmıştır.

\section{Verilerin analizi}

Nicel verilerin analizinde IBM SPSS 25.0 paket programı kullanılmıştır. Açık uçlu olarak sorulan soruya gelen cevaplardan oluşan nitel verilerin kodlama ve deşifre işlemleri ise araştırmacılar tarafından yapılmıştır. Verilerin normal dağılıp dağılmadığının belirlenmesi amacıyla Kolmogrov-Smirnov testi sonucuna $(p<0,05)$ ve Skewness ve Kurtosis değerlerine bakılmış ve verilerin normal dağılmadığı sonucuna ulaşılmıştır. Verilerin analizinde yüzde/frekans analizinin yanı sıra parametrik olmayan testlerden Mann Whitney-U ve Kruskal Wallis testleri kullanılmıştır. Büyüköztürk (2018), Kruskal Wallis testi sonucunda fark tespit edildiği durumlarda farkın hangi gruplardan kaynaklandığının tespit edilebilmesi için SPSS 18 ve üstü sürümlerde yer alan çoklu karşılaştırma testlerinin kullanılmasını bir seçenek olarak belirtmiştir. Bu bilgi doğrultusunda Kruskal Wallis testi sonucunda fark tespit edildiği durumlarda çoklu karşılaştırma testlerinden yararlanılmıştır.

\section{Bulgular}

Tablo 2: Katılımcıların Anket Sorularına Verdikleri Yanıtlar

\begin{tabular}{l|c|c|c|c|c|c|c|c|c|c}
\hline & \multicolumn{2}{|c|}{$\mathbf{1}$} & \multicolumn{2}{|c|}{$\mathbf{2}$} & \multicolumn{2}{|c|}{$\mathbf{3}$} & \multicolumn{2}{|c|}{$\mathbf{4}$} & \multicolumn{2}{|c}{$\mathbf{5}$} \\
\hline SORULAR & $\mathbf{f}$ & $\mathbf{\%}$ & $\mathbf{f}$ & $\mathbf{0}$ & $\mathbf{f}$ & $\mathbf{\%}$ & $\mathbf{f}$ & $\mathbf{\%}$ & $\mathbf{f}$ & $\mathbf{\%}$ \\
\hline $\begin{array}{l}\text { Günümüzde, insanların } \\
\text { hareket } \\
\text { karşılanması bir problem } \\
\text { haline gelmiştir. }\end{array}$ & 25 & $\mathbf{8 , 7}$ & 21 & $\mathbf{7 , 3}$ & 44 & $\mathbf{1 5 , 3}$ & 36 & $\mathbf{1 2 , 5}$ & 162 & $\underline{\mathbf{5 6 , 3}}$ \\
\hline $\begin{array}{l}\text { Halkın boş zamanlarını spor } \\
\text { aktiviteleri } \\
\text { değerlendirmelerinden ile } \\
\text { belediyeler sorumludur. }\end{array}$ & 17 & $\mathbf{5 , 9}$ & 25 & $\mathbf{8 , 7}$ & 45 & $\mathbf{1 5 , 6}$ & 54 & $\mathbf{1 8 , 8}$ & 147 & $\underline{\mathbf{5 1 , 0}}$ \\
\hline $\begin{array}{l}\text { Hizmet verdikleri bölgeye spor } \\
\text { hizmeti götüren belediyenin } \\
\text { saygınlığı artar. }\end{array}$ & 7 & $\mathbf{2 , 4}$ & 3 & $\mathbf{1 , 0}$ & 14 & $\mathbf{4 , 9}$ & 36 & $\mathbf{1 2 , 5}$ & 228 & $\underline{\mathbf{7 9 , 2}}$ \\
\hline
\end{tabular}


Çakmak, G. ve Tapşın, F.O. (2020). Belediyelerin Sunduğu Spor Hizmetlerine Yönelik Halkın Algı ve Beklentileri - Adapazarı İlçesi Örneği. Gaziantep Üniversitesi Spor Bilimleri Dergisi, 5(3), 263-275.

\begin{tabular}{|c|c|c|c|c|c|c|c|c|c|c|}
\hline $\begin{array}{l}\text { Belediye ve halk arasındaki } \\
\text { ilişkinin geliştirilmesinde spor } \\
\text { hizmetlerinin ve aktivitelerinin } \\
\text { önemli bir yeri vardır. }\end{array}$ & 8 & 2,8 & 5 & 1,7 & 22 & 7,6 & 60 & 20,8 & 193 & $\underline{67,0}$ \\
\hline $\begin{array}{l}\text { Belediyelerin yaptırmış olduğu } \\
\text { spor tesislerinin veya } \\
\text { rekreasyon alanlarının } \\
\text { işletmesi özelleştirilmelidir. } \\
\end{array}$ & 168 & $\underline{58,3}$ & 31 & 10,8 & 35 & 12,2 & 27 & 9,4 & 27 & 9,4 \\
\hline $\begin{array}{l}\text { Belediyelerin sunduğu spor } \\
\text { hizmetleri halkın ihtiyaç, } \\
\text { beklenti ve taleplerini } \\
\text { karşılamalıdır. }\end{array}$ & 7 & 2,4 & 4 & 1,4 & 8 & 2,8 & 30 & 10,4 & 239 & 83,0 \\
\hline $\begin{array}{l}\text { Spor konusundaki intiyaç ve } \\
\text { beklentileri } \\
\text { yetkililerine iletebiliyorum. }\end{array}$ & 113 & 39,2 & 51 & 17,7 & 29 & 20,5 & 36 & 12,5 & 29 & 10,1 \\
\hline $\begin{array}{lr}\text { Belediyelerin } & \text { yapmış olduğu } \\
\text { sportif } & \text { etkinliklerden } \\
\text { zamanında } & \text { haber } \\
\text { alabiliyorum. } & \\
\end{array}$ & 129 & 44,8 & 41 & 14,2 & 58 & 20,1 & 38 & 13,2 & 22 & 7,6 \\
\hline $\begin{array}{l}\text { Belediye belirli bir ücret } \\
\text { karşılığı spor hizmeti sunarsa } \\
\text { yararlanmak isterim. }\end{array}$ & 42 & 14,6 & 13 & 4,5 & 46 & 16,0 & 56 & 19,4 & 131 & 45,5 \\
\hline $\begin{array}{lr}\text { Belediyelerin } & \text { spor } \\
\text { hizmetlerindeki } & \text { ve } \\
\text { tesislerindeki başarısı siyasi } \\
\text { tercihimi belediye lehinde } \\
\text { etkiler. }\end{array}$ & 92 & 31,9 & 10 & 3,5 & 38 & 3,2 & 49 & 17,0 & 99 & 34,4 \\
\hline $\begin{array}{l}\text { Oyun ve spor alanları yapmak } \\
\text { veya yaptırmanın belediyelerin } \\
\text { görevleri arasında olduğunu } \\
\text { düşünüyorum. }\end{array}$ & 8 & 2,8 & 5 & 1,7 & 14 & 4,9 & 43 & 14,9 & 218 & $\underline{75,7}$ \\
\hline $\begin{array}{lr}\text { Yaptırdığı spor } & \text { tesislerini } \\
\text { işletmek veya } & \text { işlettirmek } \\
\text { belediyelerin } & \text { görevleri } \\
\text { arasında } & \text { olduğunu } \\
\text { düşünüyorum. } & \\
\end{array}$ & 20 & 6,9 & 11 & 3,8 & 42 & 14,6 & 57 & 19,8 & 158 & $\underline{54,9}$ \\
\hline $\begin{array}{lr}\text { Belediyelerin } & \text { mahallelerde } \\
\text { yapmış } & \text { olduğu } \begin{array}{r}\text { spor } \\
\text { tesislerinden }\end{array} \\
\text { faydalanabiliyorum. } & \text { yeterince } \\
\end{array}$ & 85 & 29,5 & 55 & 19,1 & 73 & 25,3 & 31 & 10,8 & 44 & 15,3 \\
\hline $\begin{array}{l}\text { Belediyeler spor hizmetlerini } \\
\text { siyasi tercihlere veya politik } \\
\text { kaygıllara göre mahallelere } \\
\text { götürüyor. }\end{array}$ & 76 & 26,4 & 29 & 10,1 & 61 & 21,2 & 34 & 11,8 & 88 & 30,6 \\
\hline $\begin{array}{l}\text { İlçemizde yer alan spor } \\
\text { tesisleri } \\
\text { karşılayacak sayıdadır. }\end{array}$ & 150 & $\underline{52,1}$ & 51 & 17,7 & 45 & 15,6 & 19 & 6,6 & 23 & 8,0 \\
\hline $\begin{array}{lcc}\text { İlçemizde yer alan spor } \\
\text { tesisleri } \\
\text { karşılayacak niteliktedir. }\end{array}$ & 143 & 49,7 & 51 & 17,7 & 55 & 19,1 & 23 & 8,0 & 16 & 5,6 \\
\hline $\begin{array}{l}\text { İlçemizde yer alan spor } \\
\text { tesislerinde yeterli düzeyde } \\
\text { uzman personel vardır. }\end{array}$ & 101 & 35,1 & 58 & 20,1 & 77 & 26,7 & 35 & 12,2 & 17 & 5,9 \\
\hline $\begin{array}{lr}\text { Belediye, spor } & \text { hizmetlerine } \\
\text { ilişkin yasalarda yer alan } \\
\text { görevlerini } & \text { yerine } \\
\text { getirmektedir. } & \\
\end{array}$ & 62 & 21,5 & 52 & 18,1 & 87 & 30,2 & 58 & 20,1 & 29 & 10,1 \\
\hline
\end{tabular}


Çakmak, G. ve Tapşın, F.O. (2020). Belediyelerin Sunduğu Spor Hizmetlerine Yönelik Halkın Algı ve Beklentileri - Adapazarı İlçesi Örneği. Gaziantep Üniversitesi Spor Bilimleri Dergisi, 5(3), 263-275.

Tablo 2 incelendiğinde; anket soruları içerisinde yer alan "Belediyeler spor hizmeti götürürken halkın ihtiyaç, beklenti ve taleplerini göz önünde bulundurmalıdır" ifadesine katılımcıların \%83'ü tamamen katıldıklarını, \%10,4'ü ise katıldıklarını ifade etmişlerdir. Toplamda katılımcıların \%93,4'ü bu ifadeye pozitif yönlü cevap vermişlerdir. Bu ifadeye negatif görüş bildirenlerin oranı ise yalnızca \%3,8'dir. Anket soruları içerisinde yer alan "Belediyelerin hizmet verdikleri bölgeye spor hizmeti getirmesi o belediyenin saygınlığını arttırır" ifadesine katılımcıların \%79,2'si tamamen katıldıklarını, \%12,5'i ise katıldıklarını ifade etmişlerdir. Toplamda katılımcıların \%91,7'si bu ifadeye pozitif yönlü cevap vermişlerdir. Bu ifadeye negatif yönlü görüş bildirenlerin oranı ise yalnızca \%3,4'tür. Anket soruları içerisinde yer alan "Belediyelerin görevleri arasında oyun ve spor alanları yapmak veya yaptırmak olduğunu düşünüyorum” ifadesine katılımcıların \%75,7'si tamamen katıldıklarını, \%14,9'u ise katıldıklarını ifade etmişlerdir. Bu ifadeye pozitif yönlü cevap verenlerin oranı toplamda \%90,6 iken negatif yönlü cevap verenlerin oranı \%4,5'tir. Anket soruları içerisinde yer alan "Belediye ve halk arasındaki ilişkinin geliştirilmesinde spor hizmetleri ve aktivitelerinin önemli bir yeri olduğunu düşünüyorum" ifadesine katılımcıların \%67'si tamamen katıldıklarını, \%20,8'i ise katıldıklarını ifade etmişlerdir. $\mathrm{Bu}$ ifadeye pozitif yönlü cevap verenlerin oranı toplamda $\% 87,8$ iken negatif yönlü cevap verenlerin oranı $\% 4,5$ 'tir.

Anket soruları içerisinde yer alan "Belediyelerin yaptırmış olduğu spor tesislerini veya rekreasyon (serbest zaman) alanlarının işletmesi özelleştirilmelidir" ifadesine katılımcıların \%58,3'ü kesinlikle katılmadıklarını, \%10,8'i ise katılmadıklarını ifade etmişlerdir. Bu ifadeye katılmayanların toplam oranı \%69,1 iken katıldıkları yönünde görüş bildirenlerin oranı \%18,8 seviyesindedir. Öte yandan katılımcıların \%74,7'si yapılan spor tesislerini işletmek veya işlettirmenin belediyenin görevleri arasında olduğunu, \%69,8'i ilçede yer alan spor tesislerinin intiyaçları karşılayacak sayıda olmadığını, \%67,4'ü ilçede yer alan spor tesislerinin intiyaçları karşılayacak nitelikte olmadığını, \%69,8’i halkın boş zamanlarını spor aktiviteleri ile değerlendirmelerinden belediyelerin sorumlu olduğunu belirtmişlerdir.

Tablo 3: Yaş Değişkenine Göre Kruskal Wallis Testi Sonuçları

\begin{tabular}{|c|c|c|c|c|c|c|}
\hline Yaş Grubu & $\mathbf{n}$ & Sıra Ortalaması & Ki-Kare & sd & p & Fark \\
\hline $16-25(1)$ & 36 & 140,68 & \multirow{5}{*}{10,402} & \multirow{5}{*}{4} & \multirow{5}{*}{, $034^{*}$} & \multirow{5}{*}{$3-4$} \\
\hline $26-35(2)$ & 76 & 138,38 & & & & \\
\hline $36-45(3)$ & 140 & 153,77 & & & & \\
\hline $46-55(4)$ & 24 & 100,71 & & & & \\
\hline 56 ve üzeri (5) & 12 & 174,17 & & & & \\
\hline
\end{tabular}


Çakmak, G. ve Tapşın, F.O. (2020). Belediyelerin Sunduğu Spor Hizmetlerine Yönelik Halkın Algı ve Beklentileri - Adapazarı İlçesi Örneği. Gaziantep Üniversitesi Spor Bilimleri Dergisi, 5(3), 263-275.

${ }^{*} \mathrm{p}<0,05$

Katılımcıların yaş değişkenine göre anket sorularına verdikleri yanıtlar arasında istatistiksel olarak anlamlı bir fark olup olmadığının tespit edilmesi amacıyla yapılan Kruskal Wallis testi sonucunda yaş grupları arasında istatistiksel olarak anlamlı bir farklılık olduğu tespit edilmiştir $(p<0,05)$. Farkın kaynağının tespit edilmesi için yapılan çoklu karşılaştırma testi sonucunda ise farkın 36-45 yaş grubunda olanlar ile 46-55 yaş grubunda olanların görüşleri arasında olduğu tespit edilmiştir.

Tablo 4: Eğitim Durumu Değişkenine Göre Kruskal Wallis Testi Sonuçları

\begin{tabular}{l|c|c|c|c|c|c}
\hline \multirow{2}{*}{ Eğitim Durumu } & $\mathbf{n}$ & Sıra Ortalaması & \multirow{2}{*}{ Ki-Kare } & sd & $\mathbf{p}$ & Fark \\
\hline İlkokul (1) & 24 & 156,69 & & & & \\
\cline { 1 - 3 } Ortaokul (2) & 27 & 145,91 & \multirow{2}{*}{12,558} & 4 & \multirow{2}{*}{$014^{\star}$} & $3-5$ \\
\cline { 1 - 3 } Lise (3) & 100 & 123,00 & & & \\
\cline { 1 - 3 } & 109 & 152,87 & & & & \\
\hline Lisansüstü (5) & 28 & 176,91 & & &
\end{tabular}

${ }^{*} \mathbf{p}<0,05$

Katılımcıların eğitim durumu değişkenine göre anket sorularına verdikleri yanıtlar arasında istatistiksel olarak anlamlı bir fark olup olmadığının tespit edilmesi amacıyla yapılan Kruskal Wallis testi sonucunda katılımcıların eğitim durumları arasında istatistiksel olarak anlamlı bir farklılık olduğu tespit edilmiştir $(p<0,05)$. Farkın kaynağının tespit edilmesi için yapılan çoklu karşılaştırma testi sonucunda ise farkın lise mezunu olanlar ile lisansüstü mezunu olanların görüşleri arasında olduğu tespit edilmiştir.

Tablo 5: Katılımcıların Spor Hizmetlerini Yeterli Bulup Bulmama Değişkenine Göre Mann Whitney-U Testi Sonuçları

\begin{tabular}{c|c|c|c|c|c|c}
\hline $\begin{array}{c}\text { Spor Hizmetlerini Yeterli } \\
\text { Buluyor musunuz? }\end{array}$ & $\mathbf{n}$ & $\begin{array}{c}\text { Sıra } \\
\text { Ortalaması }\end{array}$ & Sıra Toplamı & $\mathbf{U}$ & $\mathbf{Z}$ & $\mathbf{p}$ \\
\hline Evet & 80 & 176,89 & 14151,50 & \multirow{2}{*}{5728,500} & $-4,098$ & \multirow{2}{*}{, $000^{*}$} \\
\hline Hayır & 208 & 132,04 & 27464,50 & & \\
\cline { 1 - 5 }
\end{tabular}

${ }^{*} \mathrm{p}<0,05$

Katılımcıların spor hizmetlerini yeterli bulup bulmama değişkenine göre anket sorularına verdikleri yanıtlar arasında istatistiksel olarak anlamlı bir fark olup olmadığının tespit edilmesi amacıyla yapılan Mann Whitney-U testi sonucunda katılımcıların eğitim durumları arasında istatistiksel olarak anlamlı bir farklılık olduğu tespit edilmiştir $(p<0,05)$.

Öte yandan cinsiyet, meslek, ilçede ikamet ettiği süre, aylık gelir düzeyi ve düzenli olarak spor yapma durumu değişkenlerine yönelik yapılan testlerde 
Çakmak, G. ve Tapşın, F.O. (2020). Belediyelerin Sunduğu Spor Hizmetlerine Yönelik Halkın Algı ve Beklentileri - Adapazarı İlçesi Örneği. Gaziantep Üniversitesi Spor Bilimleri Dergisi, 5(3), 263-275.

katılımcıların anket sorularına verdikleri yanıtlar arasında istatistiksel olarak anlamlı bir farklılık tespit edilmemiştir.

Tablo 6: Katılımcıların İlçede Sunulan Spor Hizmetlerine Dair Beklentileri

\begin{tabular}{l|l|c}
\hline & \multicolumn{1}{|c}{ Maddeler } & \multicolumn{1}{|c}{ f } \\
\hline $\mathbf{1}$ & $\begin{array}{l}\text { Tesis sayısının arttırılması gerektiği (yüzme havuzu, tenis kortları, bisiklet yolları, } \\
\text { yürüyüş yolları vb.) }\end{array}$ & 117 \\
\hline $\mathbf{2}$ & Belediyeye ait nitelikli ve ücretsiz spor salonlarının yapılması gerektiği & 50 \\
\hline $\mathbf{3}$ & Yapılan aktivite sayısı ve spor dallarının çeşitliliğinin arttırııması gerektiği & 40 \\
\hline $\mathbf{4}$ & Spor hizmetlerinin tanıtım ve reklam faaliyetlerinin arttırılması gerektiği & 35 \\
\hline $\mathbf{5}$ & $\begin{array}{l}\text { Spor tesislerine ulaşım sorununun çözülmesi gerektiği (diğer ilçelerden merkez } \\
\text { ilçeye ulaşım ve servis eksikliği) }\end{array}$ & 30 \\
\hline $\mathbf{6}$ & $\begin{array}{l}\text { Belediye bünyesindeki yaz okullarındaki spor dalı çeşitliliğinin ve kontenjanların } \\
\text { arttırılması gerektiği }\end{array}$ & 22 \\
\hline $\mathbf{7}$ & Belediyeye ait düşük ücretli ve nitelikli spor salonları yapılması gerektiği & 20 \\
\hline $\mathbf{8}$ & Tesislerin bakımlarının daha sık ve düzenli olarak yapılması gerektiği & 20 \\
\hline $\mathbf{9}$ & $\begin{array}{l}\text { Açık spor alanı sayısı ve bu alanlardaki spor malzemesi eksikliğinin giderilmesi } \\
\text { gerektiği }\end{array}$ & 20 \\
\hline $\mathbf{1 0}$ & Kadınlara yönelik spor alanları yapılması gerektiği & 8 \\
\hline $\mathbf{1 1}$ & $\begin{array}{l}\text { Belediyelerce yürütülen spor faaliyetlerinin sadece yaz aylarıyla sınırlı kalmaması } \\
\text { gerektiği }\end{array}$ & 8 \\
\hline
\end{tabular}

Belediye tarafından sunulan spor hizmetlerini yeterli bulmayan katılımcılara yönelik olarak sorulan "sizce neler yapılmalıdır?" ifadesine gelen yanıtlar incelendiğinde katıımcıların en çok tesis sayısının azlığından bahsettiği ve yüzme havuzu, bisiklet yolu, yürüyüş yolu, tenis kortları gibi tesislerin sayısının arttırılması gerektiğine dair beyanda bulundukları tespit edilmiştir. Bu görüş katılımcılar tarafından 117 defa tekrarlanmıştır. "Belediyeye ait nitelikli ve ücretsiz spor salonlarının yapılması gerektiği (50 tekrar)", "yapılan aktivite sayısı ve spor dallarının çeşitliliğin arttırılması gerektiği (40 tekrar)" gibi ifadeler de katılımcılar tarafından sıklıkla tekrarlanan diğer ifadelerdir.

\section{Tartışma ve Sonuç}

Belediyeler, halka spor hizmeti sunan önemli kurumlardan biridir. Belediyelerin halka sunacağı spor hizmetlerini planlarken bölgenin ihtiyaç ve beklenti ve taleplerini göz önünde bulundurarak gerekli yatırımları yapması gerekmektedir. Bu doğrultuda yapılacak yatırımlar halk tarafından benimsenecek ve atıl durumda kalmayacaktır. Anket soruları içerisinde yer alan "Belediyeler spor hizmeti götürürken halkın ihtiyaç, beklenti ve taleplerini göz önünde bulundurmalıdır” ifadesine katılımcıların verdikleri yanıtlar da bu görüşü destekler niteliktedir. Katılımcıların \%93,4'ü de bu görüşe katıldıklarını belirtmişlerdir. Benzer bir şekilde Tez ve arkadaşları (2014) tarafından 
Çakmak, G. ve Tapşın, F.O. (2020). Belediyelerin Sunduğu Spor Hizmetlerine Yönelik Halkın Algı ve Beklentileri - Adapazarı İlçesi Örneği. Gaziantep Üniversitesi Spor Bilimleri Dergisi, 5(3), 263-275.

yapılan çalışmada da yerel yönetimlerin halkın beklenti ve isteklerine karşılık verebilecek programların uygulanması gerektiğini tespit etmişlerdir.

Bilindiği üzere belediyeler karar organları halkça seçilen kamu tüzel kişileridir. Görevde olduğu süre boyunca belediye yönetimlerinin halka çeşitli hizmetler sunması ve halkın gözünde bir saygınlık kazanması bir sonraki seçim için kendilerine açık bir avantaj sağlamalarına yol açacaktır. Anket soruları içerisinde yer alan "Belediyelerin hizmet verdikleri bölgeye spor hizmeti getirmesi o belediyenin saygınlığını arttırır" ifadesine \%91,7'si katıldıklarını belirtmişlerdir. Benzer bir şekilde "Belediye ve halk arasındaki ilişkinin geliştirilmesinde spor hizmetleri ve aktivitelerinin önemli bir yeri olduğunu düşünüyorum" ifadesine de katılımcıların \%87,8'i katıldıklarını belirtmişlerdir. Belediye ve halk arasındaki ilişkinin gelişmesi de hem şehrin gelişmesine katkı hem de belediye yönetimlerinin saygınlık kazanması açından önemlidir. Benzer bir şekilde Avcılar (2016) ve Munusturlar ve Çelik (2012) tarafından yapılan çalışmalarda da belediyelerin sunduğu spor hizmetlerinin saygınlığını arttıracağı sonucuna ulaşılmıştır. Çoban (2002) tarafından yapılan çalışmada ise belediyeler ile halk arasındaki ilişkinin geliştirilmesinde spor hizmetlerinin önemli bir yeri olduğu sonucuna ulaşılmıştır.

Anayasa ve diğer yasalarla belediyelere halka spor hizmeti sunma görevi verilmiştir. Belediyeler de bu görevleri doğrultusunda halka rekreatif alanlar ve spor alanları oluşturmalıdır. Anket soruları içerisinde yer alan "Belediyelerin görevleri arasında oyun ve spor alanları yapmak veya yaptırmak olduğunu düşünüyorum" ifadesine katılımcıların \%90,6'sı katıldıklarına yönelik görüş beyan etmişlerdir. Belediyeler sadece spor alanları yapmakla görevlerini yerine getirmiş sayılmazlar. Yaptıkları spor tesislerini işletmek veya işlettirmek de belediyelerin görevleri arasında olmalıdır. Benzer şekilde anket sorularından "Belediyelerin görevleri arasında yaptırdığı spor tesislerini işletmek veya işlettirmek olduğunu düşünüyorum" ifadesine katılımcıların \%74,7'si katıldıklarını beyan ederek bu görüşü desteklemişlerdir.

Katılımcıların \%69,8'i ilçede yer alan spor tesislerinin ihtiyaçları karşılayacak sayıda olmadığını, \%67,4'ü ilçede yer alan spor tesislerinin ihtiyaçları karşılayacak nitelikte olmadığını belirtmişlerdir. Anket soruları içerisinde açık uçlu olarak yer alan "Spor hizmetlerini yeterli bulmuyorsanız sizce neler yapılmalı?" sorusuna gelen cevaplar incelendiğinde bu iki ifadeye verilen cevaplar daha anlamlı olacaktır. Bu soruya katılımcıların verdiği yanıtlar incelendiğinde katılımcıların en çok "tesis sayısının arttırılması gerektiği (117 tekrar)" ifadesini ve "Belediyeye ait nitelikli ve 
Çakmak, G. ve Tapşın, F.O. (2020). Belediyelerin Sunduğu Spor Hizmetlerine Yönelik Halkın Algı ve Beklentileri - Adapazarı İlçesi Örneği. Gaziantep Üniversitesi Spor Bilimleri Dergisi, 5(3), 263-275.

ücretsiz spor salonlarının yapılması gerektiği (50 tekrar)" ifadesini belirttiği tespit edilmiştir.

Belediyelerce sunulan spor hizmetlerinin halk tarafından yeterli bulunup bulunmadığının belirlenmesi ve halkın bu konuya dair görüşlerinin tespiti amacıyla yapılan bu çalışma sonucunda aşağıdaki sonuçlara ulaşıımıştır:

- Belediyeler spor hizmeti sunarken halkın ve bölgenin ihtiyaçlarına dikkat etmelidir.

- Belediyelerin spor hizmeti sunması saygınlıklarını arttırır.

- Oyun ve spor alanları yapmak veya yaptırmak belediyelerin görevleri arasında yer almalıdır.

- Spor hizmetleri ve aktivitelerinin belediye ve halk arasındaki ilişkilerde önemli bir yeri vardır

- Yaptırdığı spor tesislerini işletmek veya işlettirmek belediyenin görevleri arasındadır.

- İlçede bulunan tesis sayısı katılımcılar tarafından yeterli bulunmamaktadır.

- Katılımcılar daha nitelikli ve ücretsiz spor salonlarının yapılmasını gerektiğini düşünmektedir.

- Katılımcılar, yapılan aktivite ve spor branşı sayısının arttırılması gerektiğini ve reklam tanıtım hizmetlerinin yeterli olmadığını belirtmişlerdir.

- Katılımcıların verdiklerini yanıtlar yaş, eğitim durumu ve spor hizmetlerini yeterli bulup bulmama değişkenlerine göre farklılık göstermektedir.

- Katılımcıların verdikleri yanıtlar cinsiyet, meslek, ilçede ikamet etme süresi, ekonomik durum, düzenli olarak spor yapıp yapmama durumuna göre farklılık göstermemektedir.

\section{Kaynaklar}

5216 Sayılı Büyükşehir Belediyesi Kanunu, (2004). T.C. Resmî Gazete, 25531, 10 Temmuz 2004.

5393 Sayılı Belediye Kanunu (2005). T.C. Resmî Gazete, 25874, 13 Temmuz 2005.

Akşar, T. (2010). Futbolun Ekonomi Politiği, İstanbul: Literatür Yayınları.

Atalay, A., Yücel, A. S., \& Korkmaz, H. M. (2016). Türkiye'de Spor Hizmetlerinin Yerelleşmesine İlişkin Belediye Başkanlarının Görüşlerinin Incelenmesi. Spormetre Beden Eğitimi ve Spor Bilimleri Dergisi. 14(1). 63-74.

Atalı, L. (2015). Büyükşehir Belediyeleri Stratejik Planlarında Spor İle IIlgili Amaç ve Hedeflerin Analizi. Spor Yönetimi ve Bilgi Teknolojileri Dergisi. 10(1). 48-56. 
Çakmak, G. ve Tapşın, F.O. (2020). Belediyelerin Sunduğu Spor Hizmetlerine Yönelik Halkın Algı ve Beklentileri - Adapazarı İlçesi Örneği. Gaziantep Üniversitesi Spor Bilimleri Dergisi, 5(3), 263-275.

Avcılar, M. (2016). Yerel Yönetimlerin Sunduğu Spor Hizmetlerine Ilişskin Halkın Görüşleri (İstanbul Çekmeköy İlçesi Örneği). Yayınlanmamış Yüksek Lisans Tezi, Bahçeşehir Üniversitesi Sosyal Bilimler Enstitüsü, İstanbul.

Baki, A. ve Gökçek, T. (2012). Karma Yöntem Araştırmalarına Genel Bir Bakış. Elektronik Sosyal Bilimler Dergisi. 11 (42). 1-21.

Büyüköztürk, Ş. (2018). Sosyal Bilimler İçin Veri Analizi El Kitabı İstatistik, Araştırma Deseni, SPSS Uygulamaları ve Yorum. (24.Baskı). Ankara: Pegem Akademi.

Büyüköztürk, Ş., Kılıç Çakmak, E., Akgün, Ö. E., Karadeniz, Ş., \& Demirel, F. (2008). Bilimsel Araştırma Yöntemleri. (1.Baskı). Ankara: Pegem Akademi.

Creswell, J.W. (2006). Understanding Mixed Methods Research. http://www.sagepub.com/upm-data/10981_Chapter_1.pdf

Çoban, B. (2002). Spor Hizmetlerine Ilişskin Halkın Belediyelerden Beklentileri (Elazığ Belediyesi Örneği). Yayınlanmamış Doktora Tezi. Gazi Üniversitesi Sağlık Bilimleri Enstitüsü, Ankara.

Çoban, B. ve Devecioğlu, S. (2006). Türkiye'deki Belediye Başkanlarının Spor Hizmetlerine İlişkin Görüşlerinin İncelenmesi. Gazi Beden Eğitimi ve Spor Bilimleri Dergisi. 11(1). 49-60.

Gürbüz, S., \& Şahin, F. (2018). Sosyal Bilimlerde Araştırma Yöntemleri FelsefeYöntem-Analiz. Ankara: Seçkin Yayıncılık.

Kurtipek, S., \& Yenel, F. (2019). Türkiye'de Yerel Yönetimler ve Spor. (2.Baskı). A. Azmi Yetim (Ed.) içinde Yönetim ve Spor. (s.431-460). Ankara: Gazi Kitapevi.

Munusturlar, S., \& Çelik, V. O. (2012). Üniversite Öğrencilerinin Yerel Yönetimlerin Bir Rekreasyon Faaliyeti Olarak Spor Hizmetleri Hakkında Görüşleri - Eskişehir Tepebaşı Belediyesi Örneği. 1.Rekreasyon Araştırmaları Kongresi.

Nunnally, J. C. (1978). Psychometric Theory. New York: McGraw Hill.

Tabachnick, B. G., \& Fidell, L. S. (1996). Using Multivariate Statistics. (3 Ed.). New York: Harper Collins.

Teixeira, M. R. C., \& Riberio, T. M. P. (2016). Sport Policy and Sport Development: Study of Demographic, Organizational, Financial and Political Dimensions to the Local Level in Portugal. The Open Sports Sciences Journal. 9(1), 26-34.

Tez, Ö., Doğan, Ö., Yavaş. Ö., Erkaya, E., Tavazar, H., \& Güzel, P. (2014). Yerel Yönetimlerde Serbest Zaman ve Rekreasyon Hizmetleri - Izmir İli Örneği. International Journal of Science Culture and Sport. 2(Özel Sayı 1), 511-524. 
Çakmak, G. ve Tapşın, F.O. (2020). Belediyelerin Sunduğu Spor Hizmetlerine Yönelik Halkın Algı ve Beklentileri - Adapazarı İlçesi Örneği. Gaziantep Üniversitesi Spor Bilimleri Dergisi, 5(3), 263-275.

Üzüm, H., Yeşildağ, B., Karlı, Ü., Ünlü, H., Parlar, F.M., Çokpartal, C., \& Tekin, N. (2016). Kamu ve Özel Spor Merkezi Müşterilerinin Hizmet Kalitesi Algılarının İncelenmesi. AiBÜ Sosyal Bilimler Enstitüsü Dergisi. 16(3). 167-180.

www.tuik.gov.tr (Erişim Tarihi: 03.08.2019).

Yücel, A.S., Atalay, A., \& Korkmaz. M. (2016). Türkiye'de Yerel Yönetimler ve Spor Hizmetleri. İstanbul: Nobel Akademik Yayıncılık.

Zengin, E., \& Öztaş, C. (2008). Yerel Yönetimler ve Spor. Sosyal Siyaset Konferansları Dergisi. (55). 49-78. 